\title{
Headache or Opportunity? National Library Week for the Academic Library
}

\author{
By ROBERT K. JOHNSON
}

National Library Week, sponsored by the National Book Committee cooperating with the American Library Association, was launched in the spring of 1958. Its first slogan, "Wake up and read," was rather strongly criticized, and the idea of the Week itself received mixed reviews. The comments on the annual slogans, as NLW's promoters pushed on with nothing if not determination, and the yearly evaluation of results by numerous sources, apparently have caused closer attention to planning and consideration of the possible effect of the slogans upon the intended recipients. It cannot be denied that there have been some impressive results if the statistics of NLW's various activities and programs are really significant; and the 1962 slogan, "Read and watch your world grow," was one of the better efforts.

The National Library Week organization indicates that much progress has been made toward its stated goals which are to produce a ". . . concerted nationwide effort to focus public attention on reading as a source of personal fulfillment, on the importance of reading in our national life, and on the libraries, which, if used fully and supported properly, can make reading materials accessible to everybody," and ". . . to help build a reading nation and to spur the use and improvement of libraries of all kinds." So far so good: hardly anyone can quarrel with such obviously constitutional pronouncements. However, even though
Dr. Johnson is Director of Libraries and Professor of Library Science at Drexel Institute of Technology, Philadelphia.

these statements seem to read largely like a public library credo (or perhaps "notes on contributions toward a philosophy of librarianship"), academic libraries certainly have not been excluded and obviously can sneak into the tent through the open door in the last quoted sentence. A number have done so, but nevertheless, numerous college and university librarians have felt National Library Week to be chiefly something for public librarians to use in the achievement of their own important goals. For the former, the thought of another activity to get into, a scheme requiring planning, coordination, promotional activities, and the related expenditure of time and labor, has created another sharp twinge in aching backlogs. The result has been that many academic librarians have seemed to agree that NLW is probably a good thing, have given it a nod in passing, with perhaps the purchase and use of some promotional aids, and then have left it up to others.

But in the meantime, what have the Faithful and the Believers in colleges and universities been doing? Tabulation by Irene Christopher, librarian of Emerson College, of 407 replies to a 1961 ACRL questionnaire showed that 324 
academic libraries participated that year in NLW as follows: community activity, 98; their own programs, 246; campus committee, 74; specific goals: standards -47, financial aid-48, other-126; activities: book sales-38, open house or coffee-61, student contests-26, convocation or assembly-51, authors' programs - 6, library exhibits - 297, outside exhibits -100 , and forum on needs -13 . Publicity media used were: campus newspaper, 214; alumni publications, 36; local newspapers, 136; local radio, 75; local TV, 25; statewide media, 16; brochures or book lists, 107; NLW promotional aids, 179. A survey of the numerous comments which were made on these questionnaires resulted in a list of a number of promising ideas for activities, some of them in cooperation with public libraries. Aside from a plea for correlation of ACRL activities with state NLW agencies, the chief criticism was that NLW materials are slanted toward public libraries and are too costly. Because of the lack of specific description, it is impossible to know exactly what some of the activities listed above actually were; and without knowing how many academic libraries received the questionnaire its validity cannot be determined. Nevertheless, this list shows a respectable participation in a number of different activities in the promotion of the Week by a nucleus of academic libraries. Probably no library could attempt to engage in all of these programs; perhaps some would be inappropriate or of little value at certain institutions or libraries, and no doubt many libraries have been carrying on their own library promotion either independently of National Library Week or in conjunction with it but without reporting in the questionnaire.

In addition to the above, it might be helpful to see what is being done by the libraries of two specific institutions, differing in size, location, purpose, student body, and support: the University of
Pittsburgh, and Connecticut College at New London. One of the general promotional ideas at the University of Pittsburgh has been an active and productive student library committee, and in part its work has been aimed purposely at promoting National Library Week in spite of the fact that some of the earlier NLW slogans were not very appropriate for college students. Among this group's activities were book drives (with mixed benefits for the library), displays arranged by committee members, and committee members' appearances on television; a personal library contest was inaugurated, and recruiting for librarianship was stressed. The library administration at Pittsburgh believes that NLW, and student participation in it, have been beneficial.

At Connecticut College some of the library promotion is aided by the college's Office of Press Relations which provides mimeographed press releases on the activities. Among the programs are senior new-book donations, a freshman book drive, book sales, and soliciting of faculty for contributions of materials (some for the library; some, like newspapers, to be sold for the benefit of the library). In addition, there have been an exhibit of new books and a senior contest for the bookplate design used for senior class books presented to the library. There is a student library committee here also. At this institution, not only are these activities not timed for a tie-in with National Library Week, but they also seem to be carried on independently of NLW entirely (or in spite of it). Connecticut College apparently has its own library week every week, but these programs represent the kind of promotion which other libraries could adopt or adapt in connection with NLW.

At this point, mention should be made of a relatively new "personal library" contest, the Amy Lovemen National Book Awards. This is an annual event, 
started in 1961-62, which could be related to NLW. Even though the winning awards at participating institutions may be announced before NLW, they could be recognized at appropriate ceremonies during NLW.

Considerable effort has been made to elicit the participation of academic librarians in NLW. In 1961, Edmon Low (then ACRL president), Felix Hirsch (chairman, ACRL Committee on Standards), and LeMoyne Anderson (ACRLNLW chairman) issued a joint appeal to college and university librarians asking help in publicizing widespread needs and inadequacies in academic library facilities and the seriousness of this situation. They stated that NLW represented an excellent opportunity to bring this information to the attention of the largest possible public, and listed nine suggested NLW activities and programs to focus attention on the ACRL Standards and the need for strong and increased support to help academic libraries meet standards. In addition, the thorough and detailed NLW Organization Handbook has contained a list of special program suggestions for colleges and universities (pp. 56-61). From the information surveyed for the present article, however, it seems that while some libraries have engaged in a number of activities and have gained much publicity as a result, a large number of college and university libraries have not jumped into the ring with full enthusiasm.

Some of the reasons which have been advanced for the reluctance of academic libraries to participate in NLW activities are: students have to read all the time anyway and this sort of appeal will not draw them; students often complain about library books, service, and librarians, and library promotion is not likely to change their minds; NLW slogans sometimes have not been very applicable to the situation in which students find themselves - "Wake up and read" (no time for more reading); "Are you well informed?" (students are likely to feel well informed already); and "For a richer, fuller life" (somewhat meaningless to students). "Build your home library" apparently was the first NLW slogan to have appeal to students, and "Read and watch your world grow" seemed to strike a responsive chord. However, in spite of the complaints and the doubts as to whether the great amount of work involved and some of the promotional activities are actually of any value, the academic libraries which already participate in NLW activities or engage in their own promotional programs seem to have found enough meat in a number of the ideas tried or suggested to make worth while the effort of testing NLW for their own purposes. Even those libraries which have done nothing with NLW must engage in some library promotion among their clientele, and it would require only a little more effort to coordinate these with NLW.

If NLW is bypassed by academic libraries it may mean the loss of a good opportunity to put a continuing and worthwhile promotional campaign into motion. Apparently for some libraries it remains to be seen how much good this sort of promotion can do; once under way an NLW program should be easy to continue, and it should not be difficult to start if a library's existing publicity programs are used as a nucleus. The coordination of a library's existing promotional activities with National Library Week (or the establishment and use of some where they are lacking) may be found to be gratifying, or may turn out to be more headache than opportunityor perhaps a mixture of both, with the benefits outweighing the disadvantages. Without a sincere attempt over time enough to try out new ideas, no one will know. It certainly seems to be worth the effort to find out. 